Article

\title{
Strengthening Efforts to Protect and Safeguard the Industrial Cultural Heritage in Montilla-Moriles (PDO). Characterisation of Historic Wineries
}

\author{
Antonia Merino-Aranda ${ }^{1}\left(\mathbb{D}\right.$, Isabel Luisa Castillejo-González ${ }^{1}\left({ }^{\circledR}\right.$, Almudena Velo-Gala $^{2}($, \\ Francisco de Paula Montes-Tubío ${ }^{1}$ (D) , Francisco-Javier Mesas-Carrascosa ${ }^{1}$ (D) and Paula Triviño-Tarradas ${ }^{1, *} \mathbb{D}$ \\ 1 Department of Graphic Engineering and Geomatics, University of Cordoba, 14071 Córdoba, Spain; \\ am.antoniamerino@gmail.com (A.M.-A.); ma2cagoi@uco.es (I.L.C.-G.); ir1motuf@uco.es (F.d.P.M.-T.); \\ fjmesas@uco.es (F.-J.M.-C.) \\ 2 Department of Prehistory, Archaeology, Ancient History, Medieval History and Historiographic Sciences \\ and Techniques, University of Murcia, 30001 Murcia, Spain; almudena.v.g.@um.es \\ * Correspondence: ig2trtap@uco.es
}

check for

updates

Citation: Merino-Aranda, A.; Castillejo-González, I.L.; Velo-Gala, A.; de Paula Montes-Tubío, F.; Mesas-Carrascosa, F.-J.; Triviño-Tarradas, P. Strengthening Efforts to Protect and Safeguard the Industrial Cultural Heritage in Montilla-Moriles (PDO).

Characterisation of Historic Wineries. Sustainability 2021, 13, 5791.

https://doi.org/10.3390/su13115791

Academic Editors: Jan K. Kazak,

Katarzyna Hodor and

Magdalena Wilkosz-Mamcarczyk

Received: 30 April 2021

Accepted: 19 May 2021

Published: 21 May 2021

Publisher's Note: MDPI stays neutral with regard to jurisdictional claims in published maps and institutional affiliations.

Copyright: (c) 2021 by the authors. Licensee MDPI, Basel, Switzerland. This article is an open access article distributed under the terms and conditions of the Creative Commons Attribution (CC BY) license (https:/ / creativecommons.org/licenses/by/ $4.0 /)$.

\begin{abstract}
Industrial heritage is linked to the cultural processes that human society sets through the traces from the past. The conservation and dissemination of this industrial-cultural heritage are crucial for sustainable urban development, and positively influences the transition to resilient and sustainable cities. The wine industry around Montilla has suffered as a result of a sharp reduction of the vineyard area in the last 25 years. Wineries, as one of the historic typologies of wine-making facilities in the Montilla-Moriles Protected Designation of Origin (PDO), as well as their materials and construction techniques, are a reference in the agricultural landscape of Montilla. Many historic wineries are the result of the abandonment and cessation of the wine industry. These buildings are linked to the agrarian activity in this area, mostly wine-making, although in some cases, they coexist with similar production processes, such as milling the fruit of the olive grove. This research characterises and analyses four historic wineries in the Montilla-Moriles PDO, which represent an example of architecture in the wine-making transformation during the 19th-20th centuries. This manuscript contributes to the attainment of some objectives set in one of the Sustainable Development Goals (SDGs), protecting and disseminating the industrial cultural heritage in Montilla-Moriles.
\end{abstract}

Keywords: sustainable development; industrial-cultural heritage; historic wineries; wine industry; Montilla-Moriles PDO

\section{Introduction}

\subsection{Agenda: Focus on the Sustainable Development Goals}

The 2030 Agenda for Sustainable Development, adopted by the United Nations General Assembly (UNGA), approved, in the year 2015, 17 Sustainable Development Goals (SDGs) for the next 13 years, [1] which are essentially focused on transforming the world. In this context, industrial agricultural heritage, including its procedures and agricultural techniques, as well as the ways of rural building, emerges as a repository of cultural resources endowed with vast power and visibility, acting as a structuring lynchpin for research. The National Plan for Industrial Heritage indicates that this type of heritage (i.e., industrial heritage) has vulnerable and occasionally misunderstood elements, which should be viewed as new cultural assets represented and interpreted through an updated scientific reading [2]. The economic, social and environmental aspects of sustainable development contribute to safeguarding the cultural heritage and nurturing creativity [3]. When the SDGs are grouped according to the three basic pillars of sustainable development (i.e., the economic, social and environmental dimensions), it is observed that culture plays a transversal role in all of them. Indeed, culture must be seen as a driver of sustainable development [4]. 
In Montilla-Moriles PDO, one of the most relevant pieces of cultural heritage is the existing wine industry in the area and its varied typology in terms of the buildings required for it, depending on the time of operation. In this context, the enhancement and dissemination of the agrarian industrial heritage in Montilla-Moriles tackles most of the SDGs, with greater influence on SDG 11 ("Sustainable Cities and Communities") in its fourth objective ("to strengthen efforts to protect and safeguard the world's cultural and natural heritage"). In our case, conserving the industrial cultural heritage in MontillaMoriles (PDO) would help the UNGA in its adoption of the "Policy for the integration of a sustainable development perspective into the processes of the World Heritage Convention". Heritage conservation contributes to making resilient and sustainable societies. The overall goal of this strategy is to guide society through appropriate support, harness the potential of heritage in general and to contribute to sustainable development [4]. While authors like Calvo-Serrano et al. [5] have shown the history of a building through its architectural sustainability level, Gullino et al. [6] have monitored the sustainability worldwide in rural heritage sites according to the architecture related to agricultural activity, to contribute and advance toward future UNESCO cultural heritage. Several of these studied sites concerned vineyards, although none of them were located in Spain. While Cano et al. [7] have supported the conservation of rural buildings as a matter of cultural tourism in Southern Spain, the industrial wine-making activity in the area has only been shown through its exhibition in museums, such as the "Wine Museum in Montilla-Moriles" or throughout the wine tourism route in Montilla-Moriles (PDO). However, such heritage has not been widely published and disseminated. So far, research related to the development of the wine industry has been limited to the technical study of production and economy, leaving aside the characterisation and defense of the architecture linked to agricultural production in the area.

This work approaches the connections between material cultural aspects and their relationship with the environment. Therefore, the aim of this study is to provide a better understanding of how this traditional architecture reflects a society whose fundamental activity was, and continues to be today, agriculture, and how it was influenced by cultural sustainability. Focusing on its protection and valorisation, despite the numerous letters and plans of protection at the national and regional level, this architecture is still unprotected, unlike the wines that are produced in this territory. The architecture of these buildings tells us, among other things, about the history and environment of this region, and reflects its society and secular tradition.

\subsection{Industrial Facilities for Wine-Making in the PDO Montilla-Moriles}

The rural space in the agrarian region of the high countryside of Córdoba is constituted by traditional buildings such as wineries, farmhouses and estates, considered in the rural scope as production units. These architectural ensembles are spatially and architecturally rich. Throughout history, in the region of Montilla-Moriles, there have existed different industrial facilities for wine-making: (i) industrial cellars; (ii) wineries, (iii) lagaretas (winepresses), and (iiii) wine-making cooperatives.

Industrial cellars were dedicated to the making and maturation of local wines. The most representative industrial cellar is the primitive cellar of Alvear, built in 1729 in the middle of the urban area of Montilla. Wineries, as defined by Naranjo-Ramírez [8], are rural houses generated by the cultivation of the vineyard, which not only attend to the industrial operations of grape grinding and fermentation of musts, but also provide accommodation to the workers of this industry, and even serve as a second home for the owner of the agricultural holding (Figure 1). Lagaretas (winepresses) are small wineries located in the urban area, unlike wineries, which are located in the agricultural holdings. The anticipated introduction of the power grid in the cities led to the integration of this type of facility in the very homes of winegrowers. Lastly, wine-making cooperatives pose a great advantage to farmers in terms of supply concentration. These were created by farmers in Moriles (1955) and Montilla (1959) [8]. 

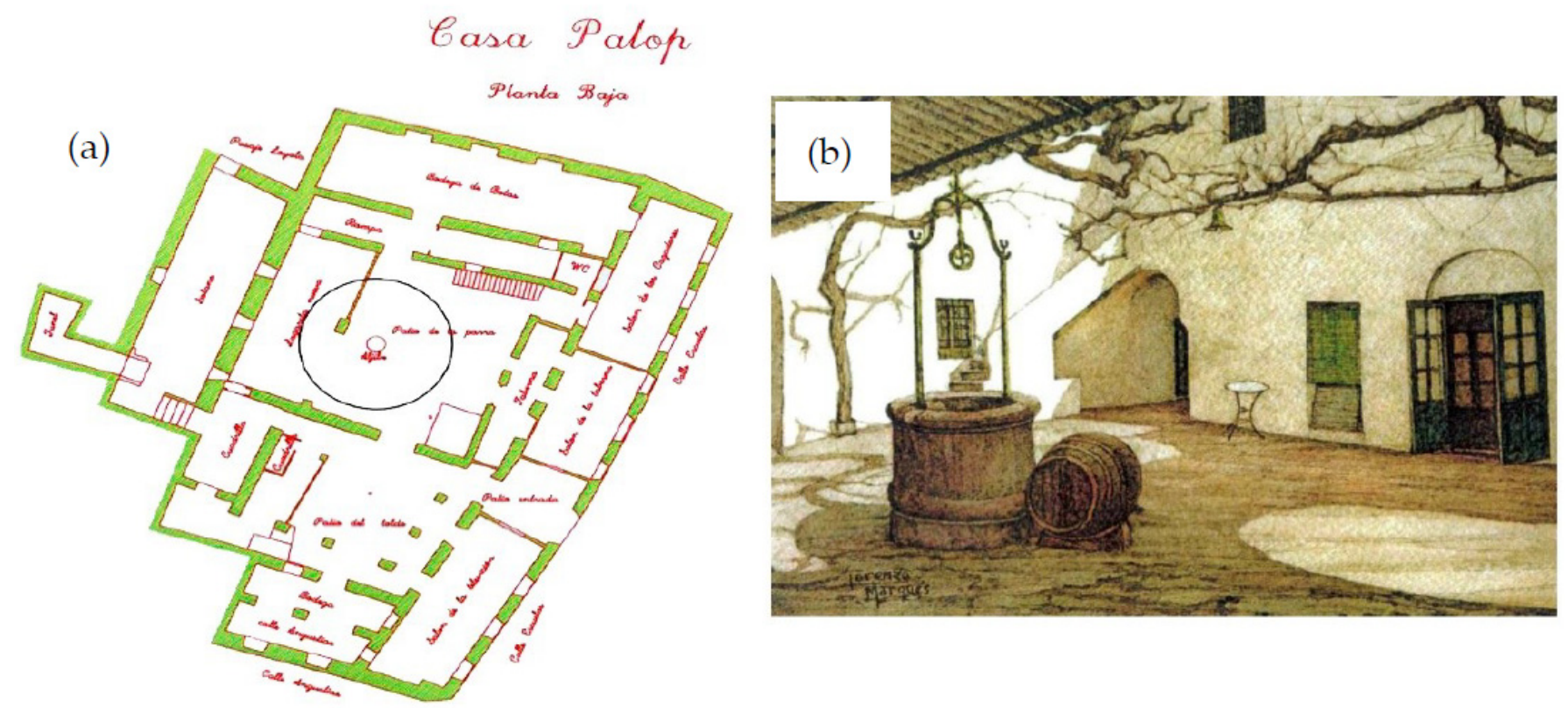

Figure 1. (a) Ground floor of Casa Palop (Palop House) in the centre of Montilla (Córdoba) [9]; (b) Drawing by Lorenzo Marqués of the current state of the patio (yard) of Casa Palop [9].

According to data from the Montilla-Moriles Regulatory Council, there are currently 40 wineries recognized as industrial heritage properties in the PDO. This industry typology demonstrates the successful integration of viticulture and sustainable development activities in this area. In this context, and according to the definition of sustainability applied to the wine-making sector, this activity can be maintained over a long period of time without depleting natural resources or causing serious damage to the environment. Regarding the constructions required for wine production, sustainability includes the use of materials present in the near environment and the use of available natural resources, thus integrating into the surrounding landscape. At the same time, the safeguarding and enhancement of this industrial heritage aim to guarantee and preserve these constructions and their territorial uniqueness and values.

\subsection{Background: First News about Wineries in Montilla}

As stated by Gullino et al. [6], rural properties, such as the abovementioned industrial facilities, are non-static features and are continuously evolving. Social, economic, and environmental changes are the main factors that impact land uses, agricultural practices and agricultural needs [10]. Indeed, rural landscapes underwent major transformations [11-13], and the Montilla-Moriles area is one example of this. Their protection and the management of PDO areas are crucial for the livelihood of the local populations and for the preservation of the traditional cultural heritage [14].

The first references about the wineries of Montilla-Moriles (Córdoba) date from the 16th, as a distinctive agricultural settlement in the area. In the year 1513, commissioned by Cardinal Cisneros, agronomist and treatise writer Gabriel Alonso de Herrera wrote the Libro de Agricultura que es de la labrança y criança, y de muchas otras particularidades y provechos del campo (Book of agriculture, concerning farming and maturing and many other particularities and uses of the field) (Valladolid: Francisco Fernández de Córdoba, 1513) (Figure 2), which was later known as Agricultura general (General agriculture) [15]. Likewise, in the book of Alonso de Herrera [16], there is a reference to the wineries of Córdoba province:

"There are three ways of harvesting. As is done in Cordova, they have their homes in the vineyards, which they call wineries, with their cellars and winepresses, and there they make their wine, and they cook it, and they let it settle, and at the time of racking they 
bring it home clean, and if there are good errands there, let them be done well and clean, this is the best thing...".

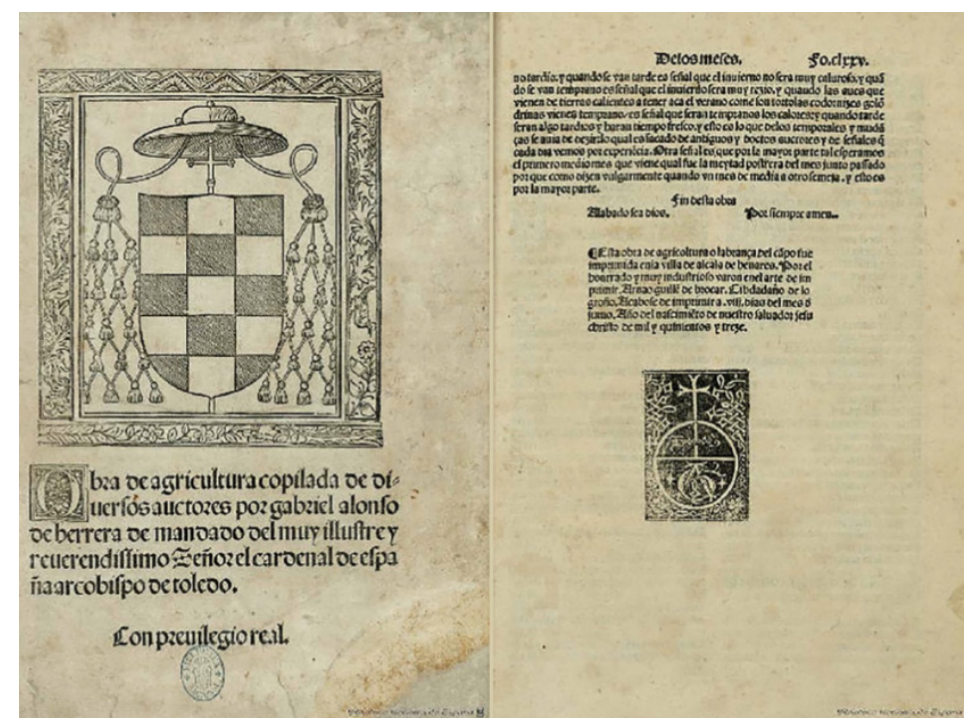

Figure 2. First edition of 1513 of the Libro de Agricultura que es de la labrança y criança, y de muchas otras particularidades y provechos del campo (Book of agriculture, concerning farming and maturing and many other particularities and uses of the field). Cover and colophon. Alcalá de Henares [17].

In that year, the lordship of Montilla was ruled by the Marquis of Priego, Mr. Pedro Fernández de Córdoba y Pacheco (1470-1517), which included the lordship of Aguilar and, in 1711, became part of the Duchy of Medinaceli (Figures 3 and 4). At the end of the lordships in 1873, in the times of María Cristina, and during the confiscation process in the mid-19th century, there was a considerable expansion of the cultivation of vineyards and the wineries associated with it [18]. Specifically, in 1845, P. Madoz [19] stated that the municipality of Montilla had 107 wineries, 28 farmhouses and 67 olive grove houses, although he did not identify the typology of such rural buildings. On his part, Ramírez de las Casas Deza [20] mentioned that Montilla had more than one hundred wineries with a good homestead.

During the second half of the 18th century, there was an increase in the litigation of small local producers against winery owners, who were mostly nobles and members of the Church [22]. This period is considered to be the starting point of the production cycle of wine in the region, where an entrepreneur agricultural middle class emerged. From the year 1860, an important wine-making industry thrived in the area of Montilla-Moriles, led by Francisco de Alvear and Gómez de la Cortina [23], Count of La Cortina, who protected the commercial work of the small farmers of the area. This was the beginning that set the foundation for the main wealth of the municipalities and their surroundings [24]. Between the years 1866 and 1888, the greatest levels of wine production were reached, due to the phylloxera plague crisis, which affected France and Italy $[25,26]$. However, the history of the vineyard in Cordoba, as well as in the whole of Spain and Europe, was dramatically truncated by this plague in the late 19th century [27]. After the phylloxera plague crisis, in the 20th century, under the protection of the rise of the wine production [8] in the entire mountainous region, numerous wineries and wine factories were built, which combined their agro-industrial nature with accommodation, constituting part of the traditional architectural heritage of the area [28]. 


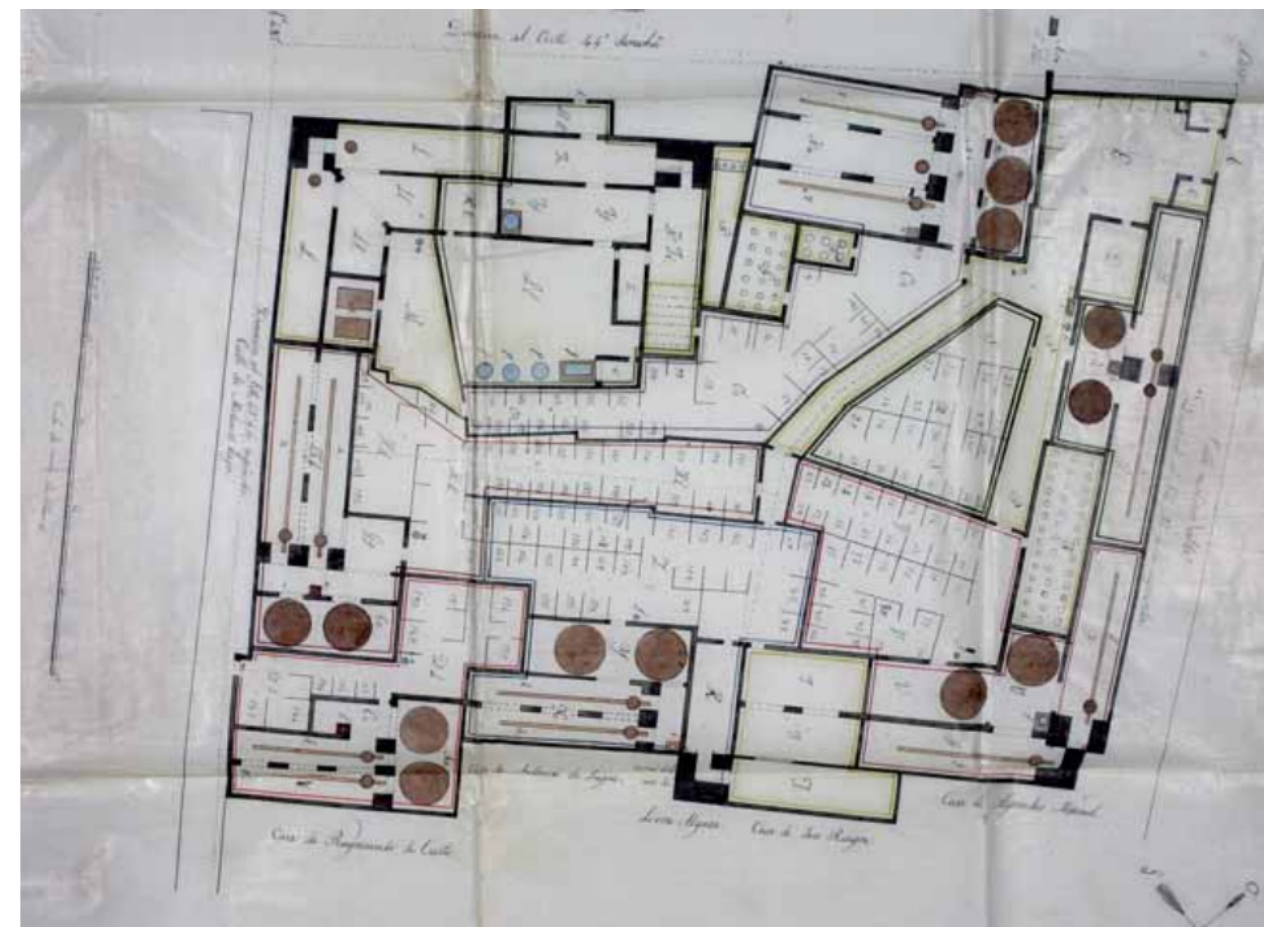

Figure 3. Ground plan of an oil mill, property of the Duke of Medinaceli in Montilla, by Benito de Mora, 1860. Priego Section, Ducal Archive of Medinaceli, Seville [18].

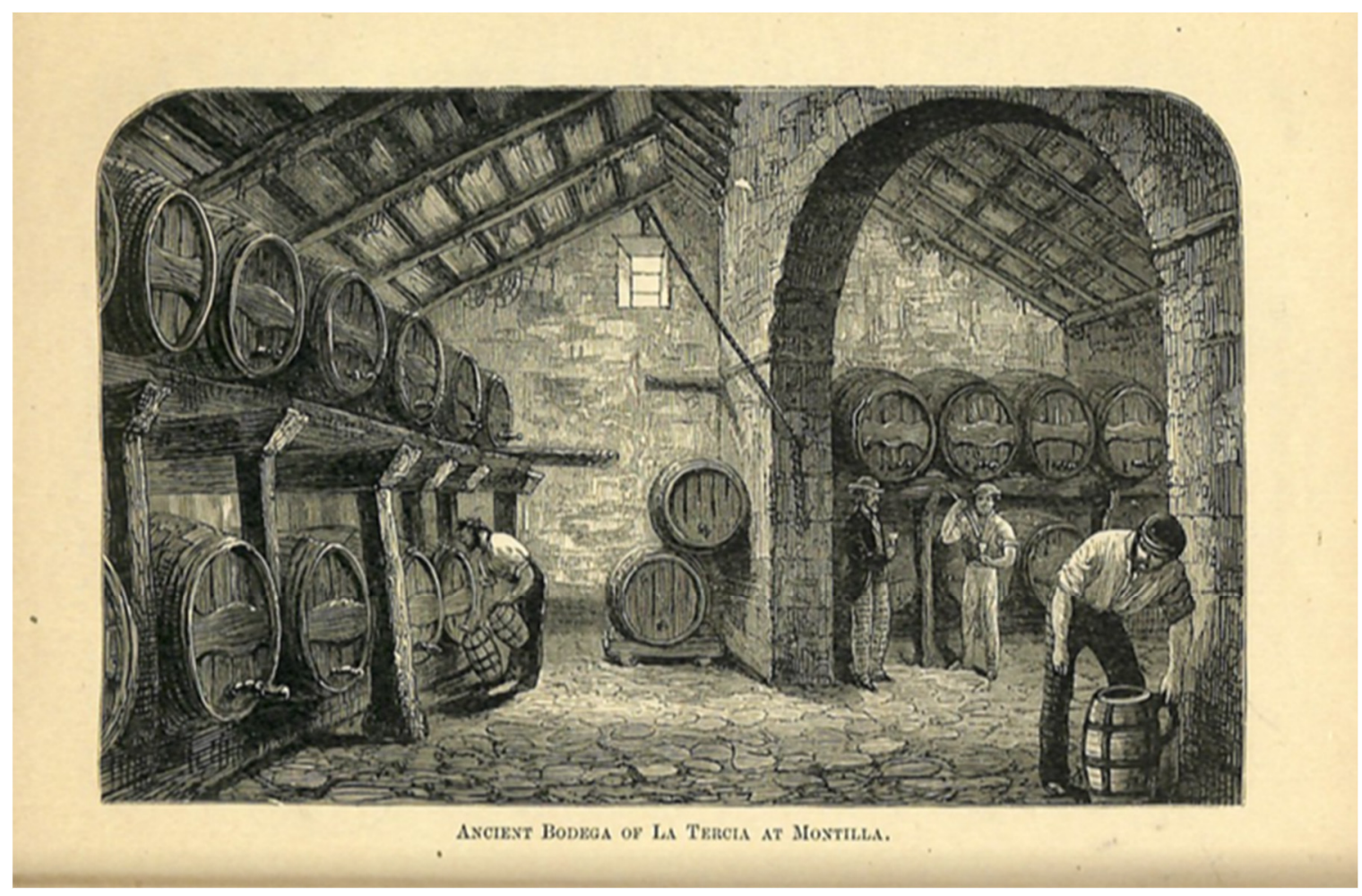

Figure 4. Engraving of "Bodega de La Tercia” (cellar) in Montilla, property of the Duke of Medinaceli, 1860 [21].

From the year 1960, the historic wineries were abandoned as a consequence of greater development of the industry and the emergence of the first wine-making cooperatives [24]. Similarly, another determining factor in the disappearance or cessation of the activity of the wineries was the decrease of land occupied by vineyards, by $70 \%$ in the last 30 years [28]. 
These reductions in the vineyard surface area, first in the 19th century with the phylloxera plague [27], and then in the 20th century with the adaptation of the law on cooperatives to the European regulations [24], were the main factors in the abandonment of this type of agricultural facilities [29].

In the Catalonian area, authors such as Llorens [26] identified the constructive features of the so-called "wine cathedrals", whereas, in Montilla-Moriles (PDO), there are few studies concerning the traditional constructions used for the industrialisation process of the wines produced. Therefore, the aim of this paper was to identify the industrialisation of the Montilla-Moriles wine production throughout history from a sustainable point of view and characterise four of the most representative wineries, as symbols of the agrarian industrial heritage in the area. Within this research, new approaches were considered to complement the scope of the industrial cultural heritage in Montilla-Moriles (PDO), from the architectural point of view. These constructions have not only contributed to economic and cultural development, but they are also a living memory of traditions, which differentiate us from other territories due to our cultural and architectural uniqueness. In terms of living culture, tradition and cultural uniqueness are reflected in the celebration of the Grape Harvest Festival, which has been held since 1816. It was King Ferdinand VII who authorised the celebration of this Fair during the first three days of September [30]. Nowadays, this cultural sustainability activity is the responsibility of the Denomination of Origin board, which is in charge of the representation, research, defense, guarantee, development and promotion of the wines produced in this region. The Montilla-Moriles Wine Route and the celebration of activities such as "Patios de bodega" offer a combination of culture and heritage in the area, in which one of its most emblematic resources is highlighted: its wineries.

\section{Materials and Methods}

The methodology followed in this research was dual. Firstly, an in-situ phase was conducted, visiting libraries and municipal archives, such as the Municipal Archive of Montilla, and the Archive Manuel Ruiz Luque, which was crucial for the data collection process. In this first phase, an exhaustive record of the historic wineries through the historical documents was carried out. Secondly, some relevant winery-owning families, such as the Alvear family, were interviewed. Thirdly, the protection figures for the safeguarding of this architectural heritage and of the territory were investigated, analysing the protection charters, in order to reflect on the current situation of protection present in the territory. Finally, each of the wineries was described and the situation of their state of conservation was analysed. The data were contrasted with previous studies on the phylloxera crisis, and also with the origins of the vineyard in Montilla-Moriles and the analysis of the technical aspects of the wine-making process in the area. All of them complement and enrich the present work, together with the rest of the literature consulted, allowing a global understanding of the architectural uniqueness and sustainability of the territory in the development of the wine industry in the Montilla-Moriles area.

In this study, we focused on a limited number of wineries, since scrutinising all the rural wine settlements in the area would go beyond the scope of this investigation.

\section{Results and Discussion}

In order to propose general guidelines and recommendations on the concept of industrial heritage, there have been numerous heritage charters written since the beginning of the 20th century, all aimed at proposing a conceptualisation, standardisation and methodology to preserve the heritage. In addition, wine tourism is currently developing this concept of architecture and landscape, including other activities such as grape harvest and gastronomic festivals [31]. As a result of this integration between architecture and the environment in which they are located, the European wine tourism charter was born. In 2003, the Nizhny Tagil Charter was drafted, where, for the first time, the fundamental importance of buildings and structures built for industrial activities were highlighted, as 
well as the territory where they are located, proposing the cataloguing, protection and maintenance according to the Charter of Venice, for their conservation. Finally, the Seville Charter of Industrial Heritage was presented in 2019, as a result of the inaction and destruction of industrial heritage, in order to update the fundamental aspects on practices regarding its protection.

Considering these aspects and values, the registration and analysis of industrial constructions become very useful tools for understanding the history of typological innovation processes and the economic structure of a territory [31].

\subsection{Conservation of Industrial Heritage}

The International Committee for the Conservation of Industrial Heritage (TICCIH), created in 1978, aims to promote international cooperation in the field of preservation, conservation, location, research, history, documentation, archaeology and revaluation of industrial heritage. There is extensive experience in the study and conservation of industrial heritage and landscapes, together with plans to enhance them, such as museums, interpretation centers and parks, as well as in the reuse of industrial buildings for other uses. The conservation of industrial heritage must involve public administrations, owners and social agents.

The examples regarding the experiences in industrial heritage conservation at the international level are varied. Some of them are: New Lanark (Scotland), Saltaire and the factories of the Derwent valley (England) and Völklingen (Germany) [32]. In Spain, among all the experiences in industrial heritage conservation, we must highlight the Almadén Mines, in Ciudad Real (Spain), registered in the World Heritage list in 2012 and, recently, adhered to the European Route of Industrial Heritage (ERIH), [33]. This case should be taken as a management and recovery model to safeguard the memory of the industrial past where landscape, buildings and machinery have been preserved and partially preserved [34].

\subsection{Heritage Importance, Heritage Values and Authenticity Attributes}

The wine-making tradition of the area is reflected in its landscape and buildings; these constitute a valuable material testimony of our history and our culture, acting as a link between the past and the present. The profound changes in agriculture and ways of life have motivated their abandonment, deterioration and, in some cases, their disappearance [35]. The industrial heritage of the Montilla-Moriles area is still little known and poorly appreciated. The own regulation of the Denomination of Origin board involves the characteristic natural factors that recognise them as unique compared to the rest of the wine-making regions. The value and authenticity of these industrial wineries are still in time to be safeguarded, jointly with the machinery and secondary elements to be preserved.

\subsection{Possible Strategies and Approaches for the Conservation of Wineries}

The functional obsolescence of these buildings and the crisis in the wine sector have led to the disuse of many wineries in recent decades. Regarding preservation, they have not had any protection figure and, after an initial period of demolitions, in recent years they have opted to give them a new use and thereby guarantee their heritage preservation. In general, heritage rehabilitation is carried out by the wine-makers themselves, who in recent times have seen the potential of wine tourism [36].

Historical precedents for the reuse and conservation of these spaces already existed: barracks in the 18th and 19th centuries in El Puerto and Jerez, schools in Jerez and social houses in Moguer at the beginning of the 20th and even bourgeois houses. The preservation of the values of this architectural heritage depends on its successful reuse [37].

The models of conservation and management of industrial heritage have a particular casuistry [38]. Institutional initiatives on winery rehabilitation are still scarce. Among the recent investments made by the General Directorate of Fine Arts and Cultural Assets of the Spanish Ministry of Culture, the project "Conservation of ethnographic heritage" affects 
five wineries [36]. Considering industrial heritage as a common thread for interventions in open spaces can contribute to combining industry, culture and nature in the creation of new avenues of wealth and well-being [38]. To this end, the institutions must be involved, so that the conservation and preservation of the wineries does not depend on the will of the wine-makers themselves. The control of the institutions over the inventories, restoration and management of assets considered as industrial heritage requires the collaboration and assistance of professionals in conservation and cataloguing tasks [36].

\subsection{The Architecture of the Wineries}

In this study, we focused on the architecture of the wineries of the study area, as one of the types of facilities used for wine production, linked to the traditional agricultural activity of the region, which was mainly based on cereals, olive groves and vineyards, and to the farmhouses and estates [39]. The latter had a stately home and accommodation for the workers, along with facilities in which the different production processes were carried out. In the mid-19th century, these buildings became exclusively wineries [8]. Some of them combined oil mills and areas for the transformation of wine, as is the case of "Lagar de la Capellanía" and "Lagar de las Monjas", and others that were exclusively dedicated to wine production, such as "Lagar de la Inglesa".

The studies conducted by [8] about these buildings specify that the wineries were within the rural houses of the Cordovan vineyard areas, and they were dedicated to different basic purposed: "To organise the agrarian activities of a vineyard exploitation; to attend to the industrial operations of grape maturation and fermentation of musts; to provide accommodation to the workers of this industry, as well as, at certain times of the year, to serve as secondary home for the owner and his family; and other, different complementary activities", among others. Construction habits are to some extent a stable element in any culture, thus it has an important impact on the shaping and sustaining of cultural landscapes [40]. Authors such as Naranjo Ramírez [8] identify the house-winery as a specific element that contributes to the agrarian landscape of Montilla with high scenic value. Regarding the building techniques, the wineries were initially predominated by whitewashed stucco factories with tiled roof on a structure of logs and cane matting. With the different renovations that took place in the 20th century, there was a combination of masonry, stucco and brick factories with tiled roofs on wooden or metal structures. These are recognisable external elements in the agrarian landscape of Montilla (Figure 5), defined by some researchers as a "fundamental reference of the human presence in the landscape and even a reference of the property and exploitation of the land" [41].

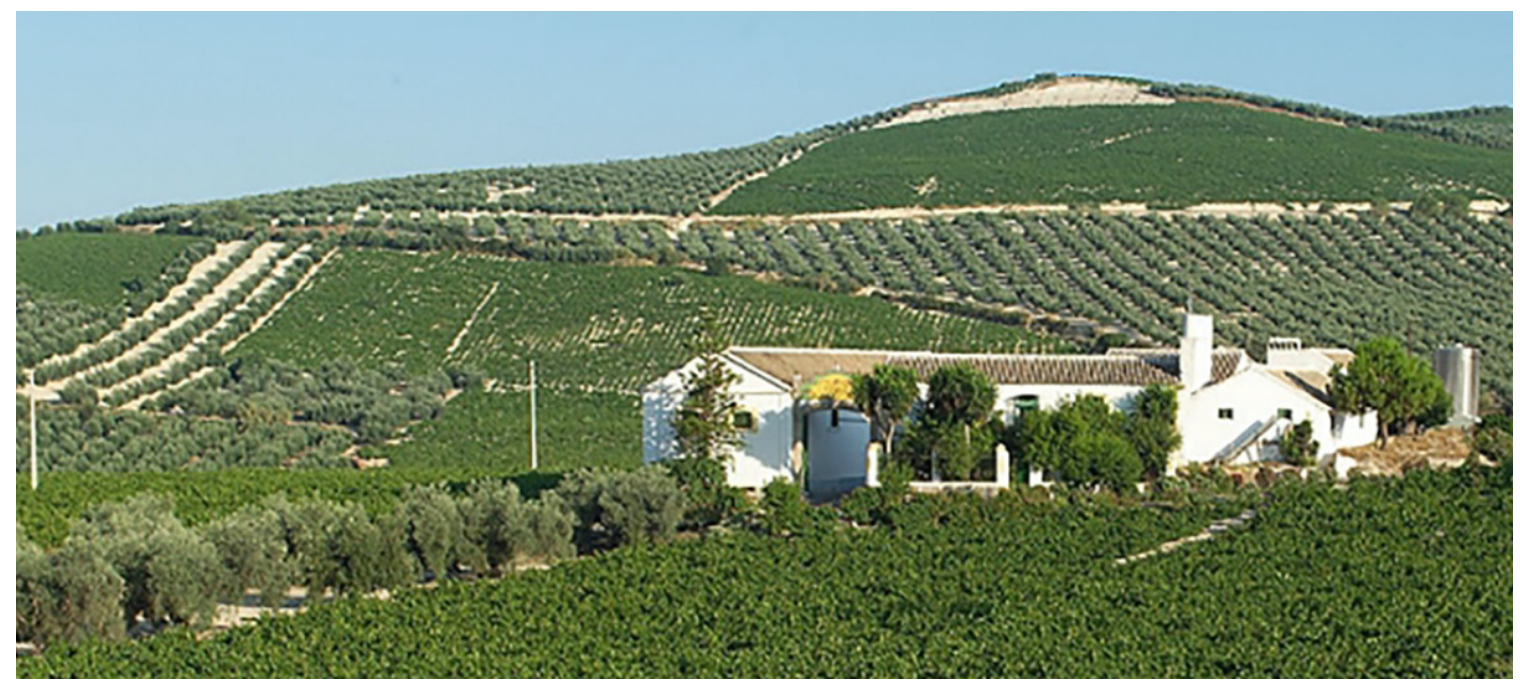

Figure 5. Landscape of Sierra de Montilla (Córdoba) with the "Lagar de los Raigones" (Montilla-Moriles wine route). 
With respect to the interior structure of the buildings, and as reported by some authors [8], the wineries are organised as blockhouses around a central yard. This yard is connected to the rest of the rooms, which were used for either agricultural activities or accommodation, providing them with daylight and ventilation. Among the rooms dedicated to industrial purposes, there were winepresses for the reception, stomping and pressing of the grapes, as well as spaces used as cellars. These particularities were observed and described in the four examples studied in this investigation.

\subsection{Historic Wineries in Montilla}

\subsubsection{Case Study: Lagar de la Capellanía (Winery of the Chaplaincy)}

The first reference to this winery is in a document written by Mrs. Luisa Ward of Alvear (Figure 6) in 1834, in which she declared to be, along with her brother-in-law Manuel (clergyman), the owner of the first hydraulic press installed in their oil press of El Carril, in the municipality of Montilla. In this text, she also mentions another oil press/winery of their own located in the plain of El Mesto, known as the Chaplaincy. The project for the construction of the Chaplaincy (Figure 7) has an oil mill and a winery in the Chaplaincy of Alvear, which was constituted by: (a) a front façade; (b) an entrance to the sections; (c) the sections (rooms first and then cellars); (d) an old section; (e) a well; (f) stables; (g) a stomping winepress; $(\mathrm{j})$ presses with their regaifas (circular stone slabs for milling); $(\mathrm{k})$ a common well; (h) solid towers; (y) a well for musts; and (l) a lever winch. Currently, the "Lagar de la Capellanía" maintains its original structure and the yard connected to the rooms, although it has undergone different expansions and the use of its spaces has changed.

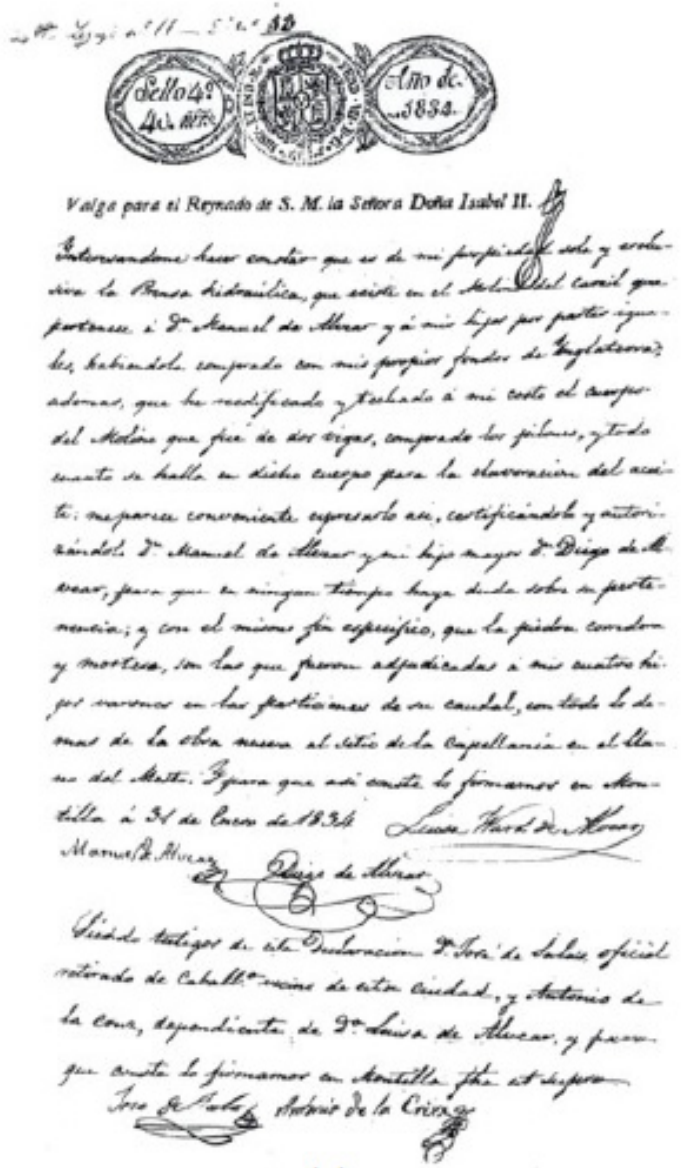

(a)

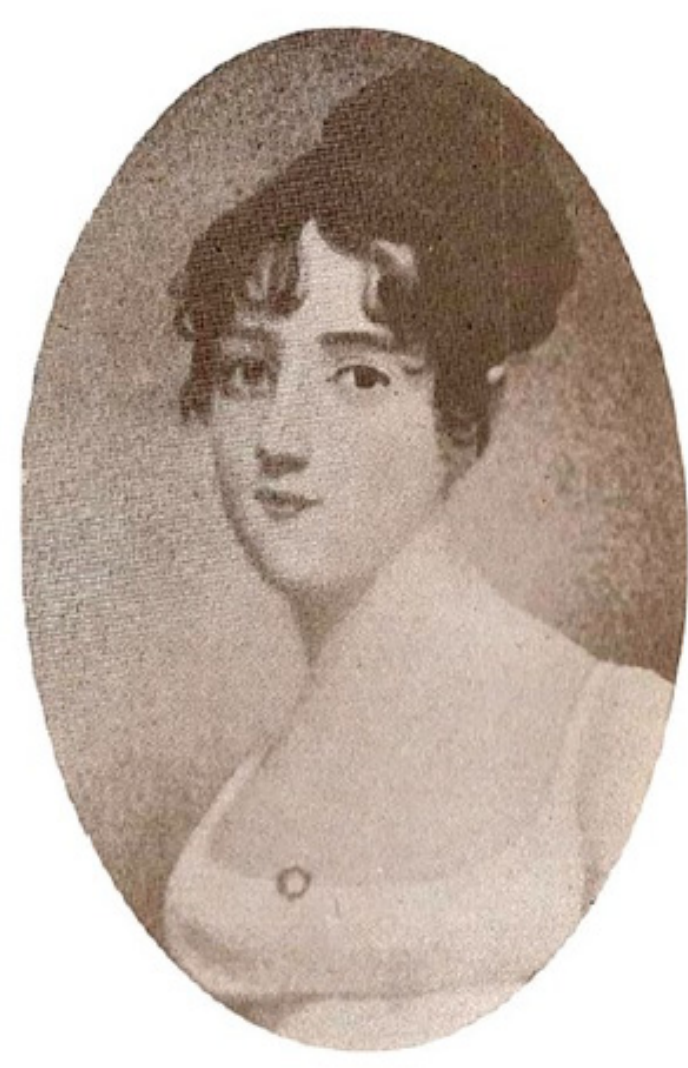

(b)

Figure 6. (a) Document of the declaration of property of the first hydraulic press installed in the oil press of El Carril, in the municipality of Montilla (Córdoba), written by Mrs. L. Ward of Alvear and her brother-in-law Manuel (clergyman) in 1834. Archive of the Alvear family [42]; (b) portrait of Mrs L. Ward of Alvear (photograph provided by Mª J. Jiménez Alvear). 


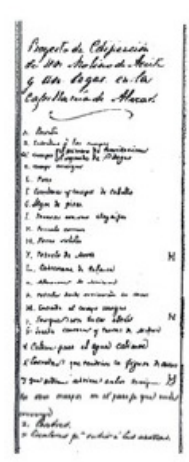

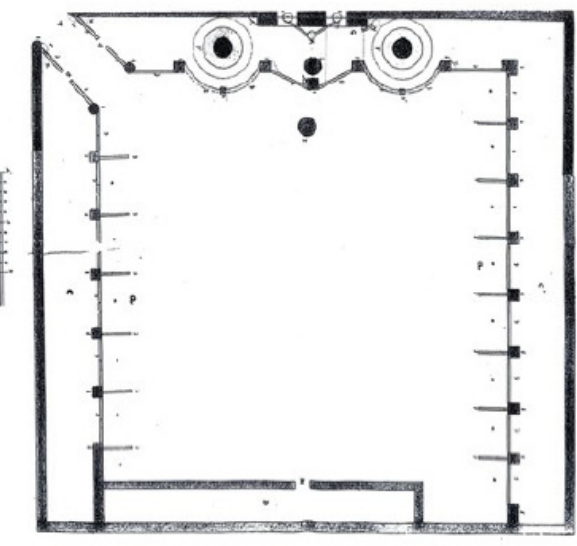

(a)

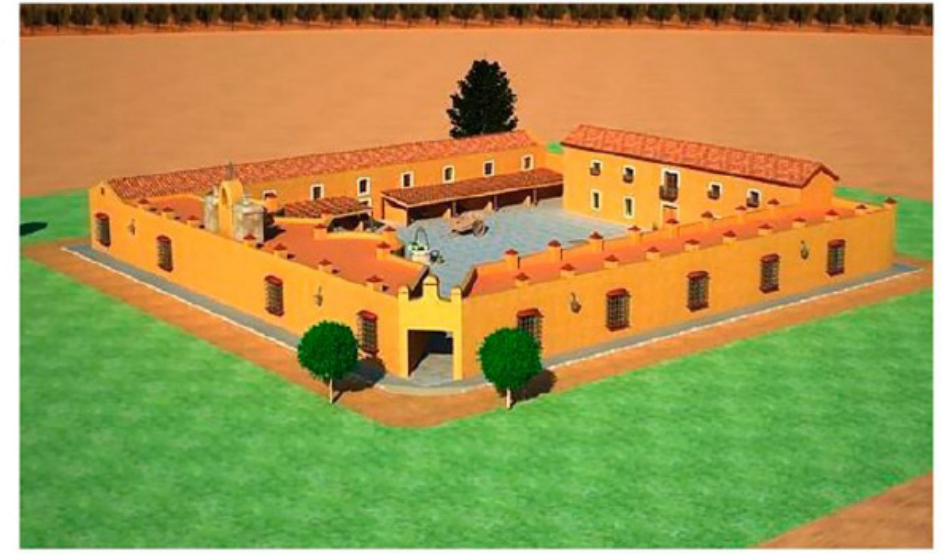

(b)

Figure 7. (a) Construction project of the "Molino y Lagar de la Capellanía" (mill and winery of the chaplaincy). Archive of the Alverar family [42]; (b) reconstruction of the "Lagar de la Capellanía" [42].

\subsubsection{Case Study: Lagar "el Parador de Montilla" (The Montilla Inn Winery)}

During the reign of Elizabeth II, specifically on 20 July 1856, Montillian landowner Francisco Solano Rioboó requested the construction of a winery. Interested in agriculture, he sent a report to the sub-delegation of Córdoba in 1834, describing the economic utility of this type of buildings in olive milling [43], as well as the use of a machine brought from London by Mr. Diego of Alvear. A year later, the construction of the so-called Montilla Inn began.

In the documents analysed for the present study, provided by the Municipal Archive of Montilla, Mr. Francisco Rioboó informed the mayor of Montilla about the compliance with the road ordinances and the delineation performed by the overseer, Mr. R. Arjona (Figure 8). The reply of the mayor, Mr. Juan Mariano Algaba, highlighted the social interest of this investment and the granting of the license for the construction of the "Casa Lagar" (winery house), after the verifications and recommendations of the district engineer, the assistant of the Córdoba-Málaga road and the overseer. One year after its construction, this building had two bodies: one originally designed and used for accommodation, where the landlords lived and travelers were received, and another one reserved for the stable, the haystack, the winepress for grape stomping and a cellar with large earthenware jars. Both bodies were connected by another two bodies located to the right and to the left of the main bodies, forming a central square yard between them.

Some years after the events that occurred in Montilla as a result of the proclamation of the First Spanish Republic, which ended with the death of the wealthiest landowner of the region, Francisco Solano Rioboó, in 1877, "Casa Lagar" was already known as "Parador de la Concepción", and was inherited by devotee $\mathrm{M}^{\mathrm{a}}$ Encarnación Rioboó y Ortiz.

The name "El Parador" comes from its primitive use, which was made compatible with that of the winery, as it was a stop for stagecoaches traveling to Seville, Málaga and Córdoba. Aguilar Montesinos [45] conducted a virtual reconstruction of this building, which is published on a Youtube channel. In 1900, through barter, the building was purchased by the Trillo-Figueroa family, who then sold it in 1907. After going through different owners, it was bought by the founder of the Cobos cellars, Mr. J. Cobos Ruiz, in 1907, who named it "Parador de San Francisco Solano", although it was exclusively used as a winery and cellar (Figure 9). Today it is a ruined building.

\subsubsection{Case Study: Lagar de La Inglesa (Winery of the English Woman)}

The "Lagar de La Inglesa" (winery of the English woman) is one of the most significant wineries of Montilla, for both its history and its architecture. It is located in the mountainous region of Montilla, in the neighbourhood of "La vereda del Cerro Macho", in one of the 
areas of greatest scenic and wine interest. Its name refers to English lady Luisa Rebeca de Ward, who was married to Mr. Diego de Alvear y Ponce de León. It was built in 1870, possibly by Mr. Francisco de Alvear y Ward (1817-1896), father of the Count of La Cortina. This building was renovated in successive interventions, until the Count of La Cortina, Francisco de Alvear y Gómez de la Cortina, gave it the look that is fully preserved today.

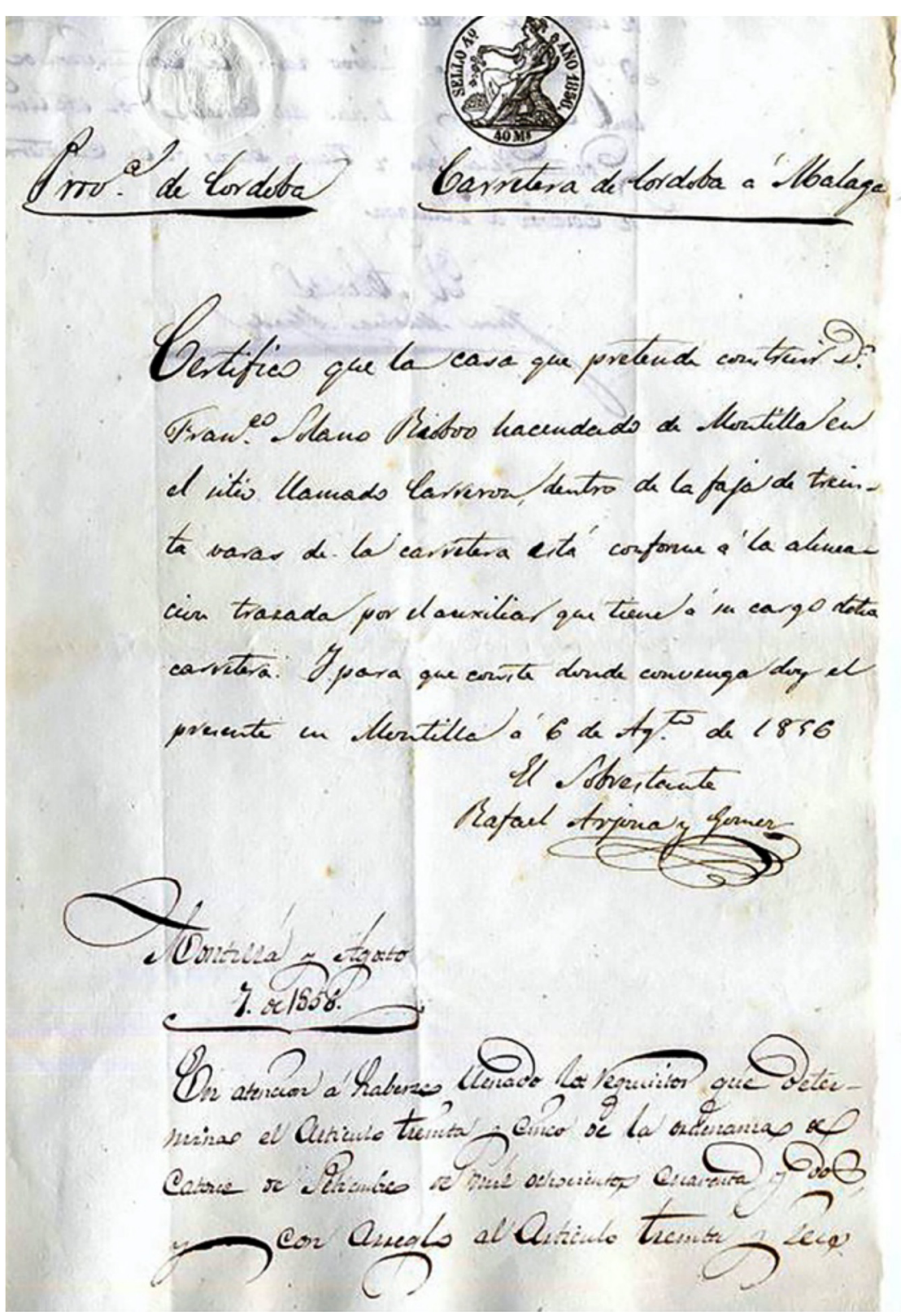

Figure 8. Certification of August 6th, 1856 from overseer Mr. R. Arjona about the measurements for the construction of the Montilla Inn (Córdoba) [44].

The "Lagar de La Inglesa" is a mansion of pure English style, perfectly preserved by its current owner, wine producer Antonio Doblas (Moriles). The different rooms are distributed in a rectangular plan around a central yard (Figure 10). The building is entered through a tower-like central body, finished by an accessible terrace that was used as a lookout (Figure 11), and its interior includes: the hall, the lordly rooms and the staircase. The back of the building was crowned with the bell-gable of a chapel facing the interior of the yard [46]. Moreover, there is a large storage room under the roof along the entire building, which completes the service rooms. Initially, this house was a winery and a 
cellar; currently, grapes are not ground in it, since the fermentation cones were removed. However, wine is matured there in wooden barrels. Therefore, it is only considered a cellar, with over 600 casks of American oak.

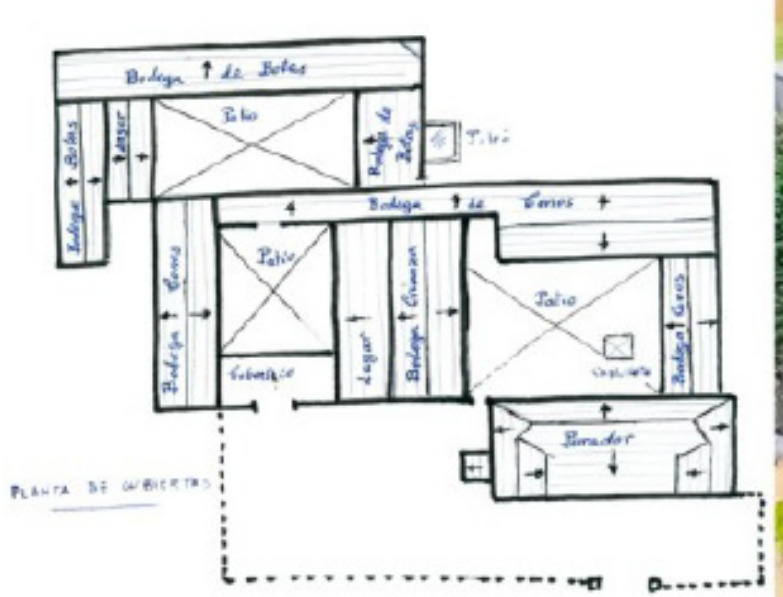

(a)

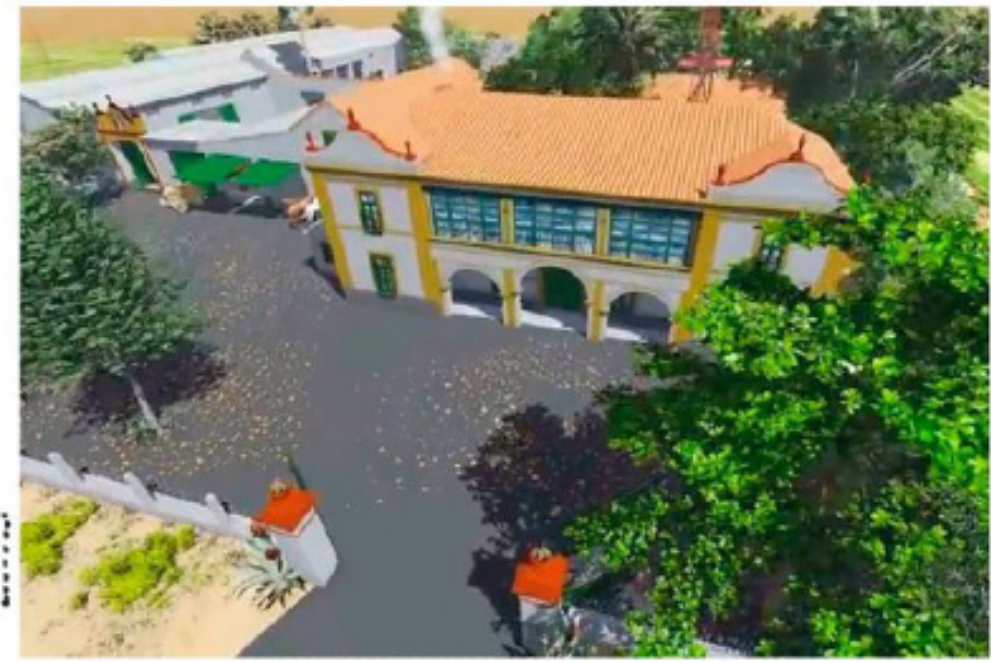

(b)

Figure 9. (a) Roof plan of "Lagar el Parador" in Montilla (Córdoba) (Image provided by Francisco de Paula Montes Tubío); (b) panoramic view of the virtual reconstruction of "Lagar el Parador" [45].
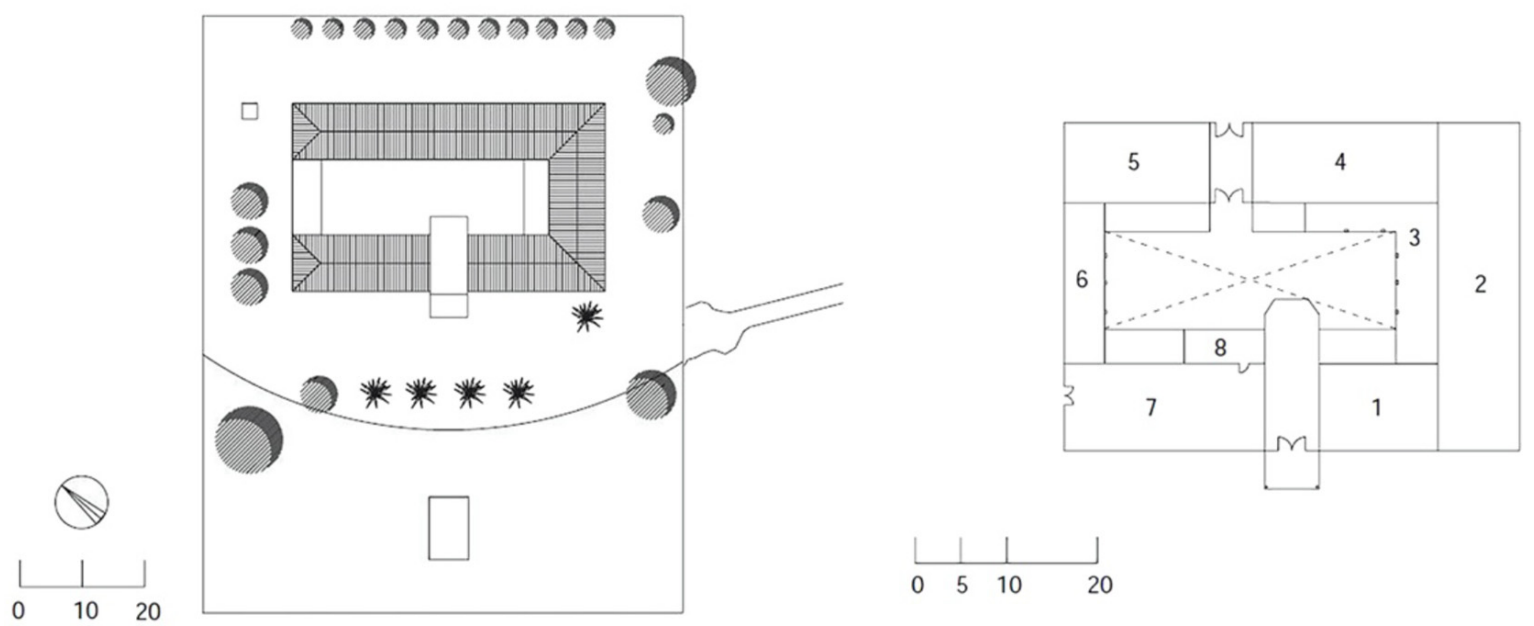

Figure 10. Ground plan of the "Lagar de La Inglesa" in Montilla (Córdoba): (1) lordly rooms; (2) maturation cellar in the ground floor and lordly rooms in the upper floor; (3) winepress; (4) winery; (5) kitchen in the ground floor and staff rooms in the upper floor; (6) old stable; (7) chapel; (8) vestry [18].

Brick is the main material used in the construction of the façades, with both building and ornamental purposes [47]. This is one of the multiple manifestations of clay, an autochthonous material that was widely used in the winery house [8]. This material was used to build, cover holes and outline horizontal bands that simulate the traditional mudéjar factory; in addition, worked in detail, it appears in the ledge and the high frieze of geometric decoration that surmounts the upper floor, thus gaining height [18]. 


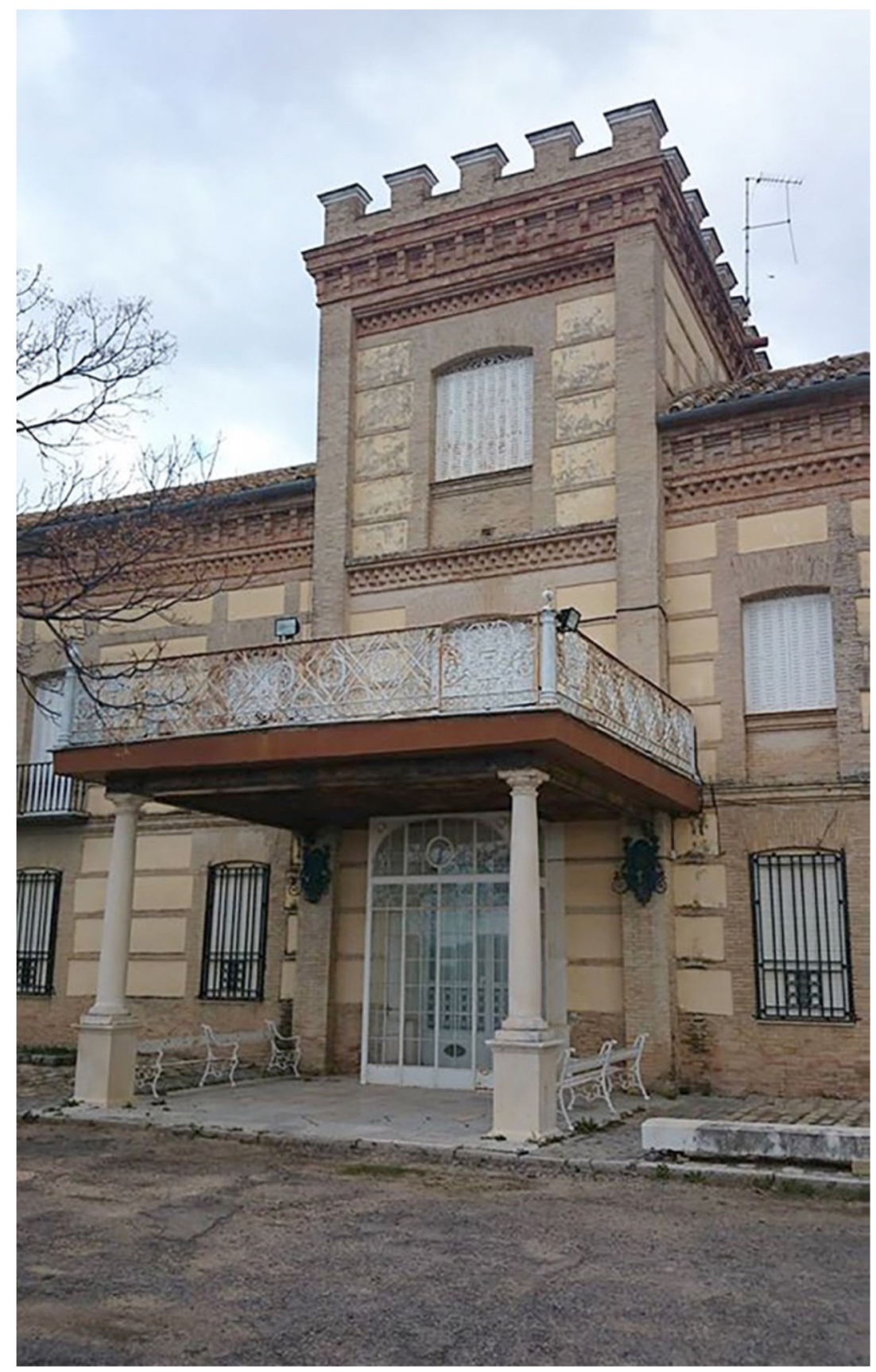

Figure 11. Entrance façade to the "Lagar de La Inglesa" (photograph provided by Francisco de Paula Montes Tubío).

\subsubsection{Case Study: Lagar de Las Monjas (Winery of the Nums)}

The "Lagar de Las Monjas" (winery of the nuns) is located in the mountainous regions of Montilla, in the area of higher quality, $5 \mathrm{~km}$ from Montilla and $2.5 \mathrm{~km}$ from the "Lagar de La Inglesa". The first document about this building dates from the year 1722, with the following description: "Old oil mill founded by the convent of Santa Ana in the year 1722. It preserves the press nave, divided by a central arcade and covered by a gable roof of ceramic tiles. It also has stables, storage rooms and other work rooms connected to adjacent yards. It preserves the front façade with an engraving of Santa Ana, ceiling stones and the spindle of the beam press integrated in the building itself. It was later transformed into an industrial oil mill. It is currently in poor state of preservation, with the roof partially torned down." (Figure 12). 
(a)

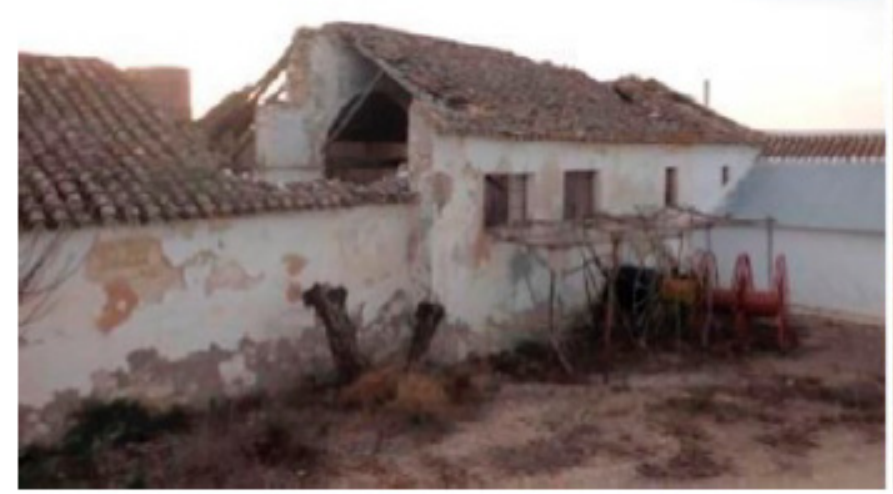

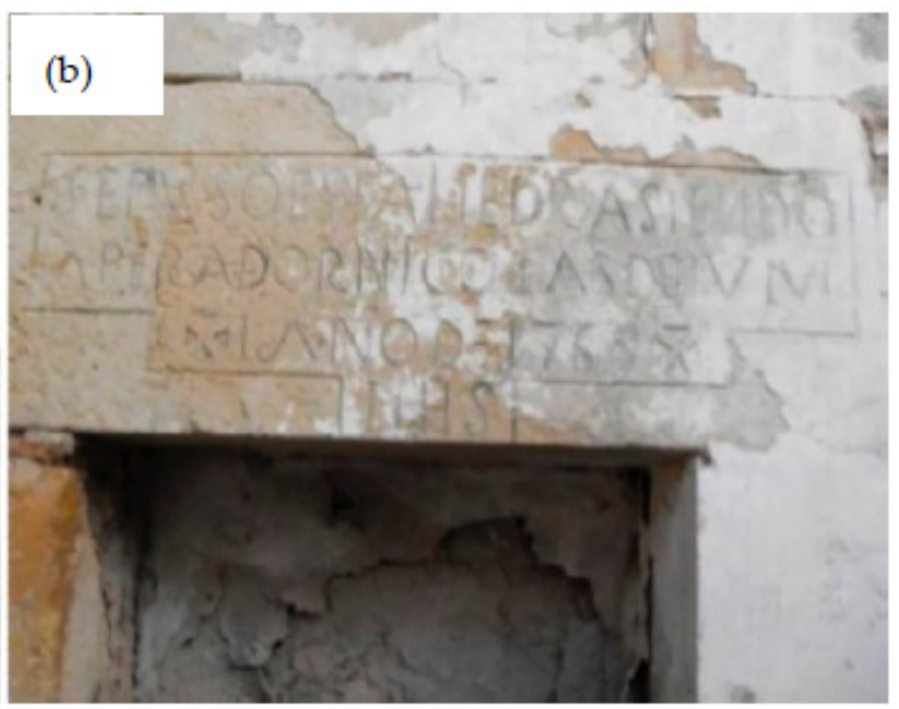

Figure 12. (a) State of the roof, partially torn down, of the "Lagar de Las Monjas" in Montilla (Córdoba) [43]; (b) lintelled stone signed by the implementer in the year 1769 in the mill of the "Lagar de las Monjas" [43].

In 1853, the "Lagar de Las Monjas" was turned into an industrial oil press, likely coinciding with the ecclesiastical confiscation or with its purchase by individuals, which is its current use. However, in 1974, the owner of the Las Monjas country house, Mrs. Elisa Valderrama Rioboó, ordered the construction of a cellar and a winery (Figure 13) for her own vineyard exploitation.

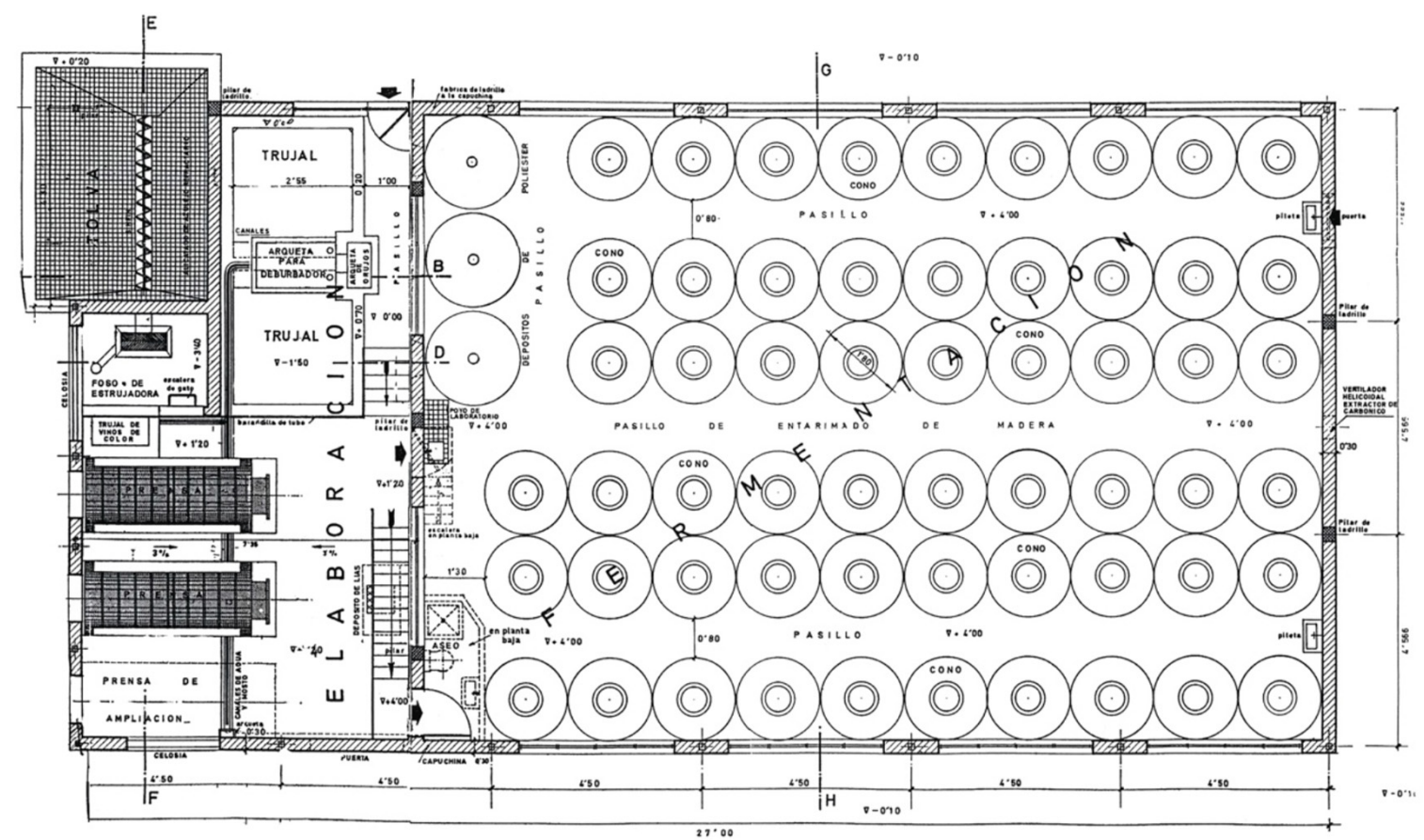

Figure 13. Ground plan of the production nave as of 1974 of the "Lagar de las Monjas" in Montilla (Córdoba) [48].

\section{Conclusions}

This paper describes the most prominent features of the historical wineries in MontillaMoriles (PDO). The novelty of this paper is that it presents the description of these four representative wineries in the Montilla-Moriles area, from the data collected in the unpublished files that address these particular constructions, as part of the industrialisation of 
wine production, and valuable heritage insights that should be preserved for the future sustainable development.

The analysis conducted in this study indicates that the architecture of the historic wineries of Montilla is identified by the autochthonous materials used, such as stone, the masonry, stucco and brick factories and the roofs, generally gable roofs on wooden structures. Their design follows a traditional model, characterised by the main yard around which a set of rooms are distributed, including the accommodation area.

As a consequence of the decrease in the land area occupied by vineyards, and due to the greater reception capacity of wine-making cooperatives, numerous historic wineries have disappeared or nearly disappeared in Montilla, such as the "Lagar del Parador", which is in the red list of the heritage, near collapse and at imminent risk of falling down. None of the examples presented in this study have reached the present time with their original role of fruit transformation that was carried out in them; only the "Lagar de la Inglesa" maintains the maturation cellar.

To sum up, the physical abandonment ruin of numerous wineries has a negative effect on the Montillian landscape, where they stood out for the traditionality of the agrarian region in which they were located, being also part of our identity. With their disappearance, as is the case of "El Parador" and the "Lagar de La Capellanía", an important part of the industrial cultural heritage of Montilla-Moriles (PDO) is lost, and only other alternatives resources, such as virtual reconstructions $[49,50]$, allow preserving the historical memory of these buildings. The identification of these historic wineries based on old literature documentation and local people's inner insights through interviews is indisputably important for cultural value conservation, fostering cultural sustainability. This manuscript helps to conserve and spread the word about the fundamental features of traditional old wineries, as industrial cultural assets.

To sum up, protecting and disseminating the industrial cultural heritage in MontillaMoriles (PDO) would help policymakers in its adoption concerning a more sustainable cultural policy, ensuring the sustainability of rural world heritage sites.

Author Contributions: Conceptualization, A.M.-A. and F.d.P.M.-T.; methodology, A.M.-A. and F.d.P.M.-T.; validation, A.M.-A., F.d.P.M.-T. and I.L.C.-G.; investigation, P.T.-T. and A.V.-G.; writingoriginal draft preparation, A.M.-A., F.d.P.M.-T. and P.T.-T.; writing-review and editing, F.-J.M.-C. and P.T.-T.; supervision, I.L.C.-G., F.-J.M.-C. and P.T.-T. All authors have read and agreed to the published version of the manuscript.

Funding: This research received no external funding.

Conflicts of Interest: The authors declare no conflict of interest.

\section{References}

1. United Nations. Sustainable Development Goals. The Sustainable Development Agenda. 2019. Available online: https: //www.un.org/sustainabledevelopment/development-agenda/ (accessed on 18 April 2021).

2. Ministerio de Cultura. El Plan Nacional de Patrimonio Industrial ("The National Plan for Industrial Heritage"). Madrid. 2011. Available online: http:/ / www.culturaydeporte.gob.es/planes-nacionales/dam/jcr:b34f01e5-c3d9-497b-bc7a-ecba1ac65d22 / 04-industrial-eng.pdf (accessed on 16 April 2021).

3. Serrano, E.; González-Amuchastegui, M.J. Cultural Heritage, Landforms, and Integrated Territorial Heritage: The Close Relationship Between Tufas, Cultural Remains, and Landscape in the Upper Ebro Basin (Cantabrian Mountains, Spain). Geoheritage 2020, 12, 86. [CrossRef]

4. UNESCO. Culture for the Agenda 2030; United Nations Educational, Scientific and Cultural Organizations: Paris, France, 2018; Available online: http:/ / www.unesco.org/culture/flipbook/culture-2030/en/Brochure-UNESCO-Culture-SDGs-EN2.pdf (accessed on 27 April 2021).

5. Calvo-Serrano, M.; Castillejo-González, I.; Montes-Tubío, F.; Mercader-Moyano, P. The Church Tower of Santiago Apóstol in Montilla: An Eco-Sustainable Rehabilitation Proposal. Sustainability 2020, 12, 7104. [CrossRef]

6. Gullino, P.; Beccaro, G.L.; Larcher, F. Assessing and Monitoring the Sustainability in Rural World Heritage Sites. Sustainability 2015, 7, 14186-14210. [CrossRef]

7. Pj, C.M.S. Preservation and Conservation of Rural Buildings as a Subject of Cultural Tourism: A Review Concerning the Application of New Technologies and Methodologies. J. Tour. Hosp. 2013, 2, 1000115. [CrossRef] 
8. Naranjo Ramírez, J. El valor paisajístico de lo utilitario. La casa rural en el viñedo cordobés: "los lagares". In En: Martínez De Pison, E. Y Ortega Cantero, N.; del Paisaje, L.v., Ed.; Autonomous University of Madrid: Madrid, Spain, 2019; pp. $293-316$.

9. Portero Laguna, J. Metodología Para El Conocimiento De Un Edificio Agroindustrial Integrando Distintas Disciplinas. Ph.D. Thesis, University of Cordoba, Córdoba, Spain, 2017.

10. Triviño-Tarradas, P.; Carranza-Cañadas, P.; Mesas-Carrascosa, F.-J.; Gonzalez-Sanchez, E.J. Evaluation of Agricultural Sustainability on a Mixed Vineyard and Olive-Grove Farm in Southern Spain through the INSPIA Model. Sustainability 2020, $12,1090$. [CrossRef]

11. Landi, S. Rural Landscapes of the 20th Century: From Knowledge to Preservation. Arch. Civ. Eng. Environ. 2019, 12, 47-56. [CrossRef]

12. Slámová, M.; Belčáková, I. The Role of Small Farm Activities for the Sustainable Management of Agricultural Landscapes: Case Studies from Europe. Sustainability 2019, 11, 5966. [CrossRef]

13. Prada Llorente, E.I.; Riesco Chueca, P.; Herrero Tejedor, T. Landscape and image: Heritage and form in the cultural construction of agrarian land. Estudios Geograficos 2013, 74, 557-583. [CrossRef]

14. Vlamia, V.; Kokkorisb, I.P.; Zogarisc, S.; Cartalisd, C.; Kehayiasa, G.; Dimopoulos, P. Cultural landscapes and attributes of "culturalness" in protected areas: An exploratory assessment in Greece. Sci. Total Environ. 2017, 595, 229-243. [CrossRef] [PubMed]

15. Quirós García, M. El Libro de Agricultura de Gabriel Alonso de Herrera: Un texto en busca de edición. Criticón 2015, 123 , $105-131$. [CrossRef]

16. Herrera, G.A. El Libro De Agricultura. In Libro Segundo; 1790; Volume CXXI, p. 71. Available online: http://bdh-rd.bne.es/ viewer.vm?id=0000079905\&page $=1$ (accessed on 20 May 2021).

17. MAPA. Ministerio de Agricultura, Pesca y Alimentación. Gobierno de España. Obra de Agricultura, 1513. Primera Edición. 2020. Available online: https:/ / www.mapa.gob.es/es/ministerio/servicios/informacion/plataforma-de-conocimiento-parael-medio-rural-y-pesquero/centenario/indice-1513.aspx (accessed on 12 April 2021).

18. Junta de Andalucía. Consejería de Fomento, Infraestructuras y Ordenación del Territorio. Cortijos, haciendas y lagares: Arquitectura de las grandes explotaciones agrarias de Andalucía. Provincia de Córdoba. Sevilla. 2006. Available online: https://ws147.juntadeandalucia.es/obraspublicasyvivienda/publicaciones/01\%20ARQUITECTURA\%20Y\%20VIVIENDA/ cortijos_haciendas_y_lagares_en_andalucia/cortijos_haciendas_cordoba/cordoba_tomo2.pdf (accessed on 28 April 2021).

19. Madoz, P. Diccionario Geográfico-Estadístico-Histórico De España Y Sus Posesiones De Ultramar; Establecimiento tipográfico de P. Madoz y L. Sagasti: Madrid, Spain, 1845; Volume 11.

20. Ramírez de las Casas Deza, L.M. Corografía Histórico-Estadística De La Provincia Y Obispado De Córdoba (1840-1842); Monte de Piedad y Caja de Ahorros: Cordoba, Spain, 1840.

21. Vizetely, H. Facts about Aherry Gleaned in the Vineyards and Bodegas of Jerez, Seville, Moguer \& Montilla Districts during the Autum of 1875. Londres, 1876. Ward, Lock, and Tyler, Warwick House. Available online: https:/ / euvs-vintage-cocktail-books cld.bz/1876-Facts-About-Sherry-by-Henry-Vizetelly/X/ (accessed on 16 April 2021).

22. IAPH (Instituto Andaluz del Patrimonio Histórico). Paisaje Vitivinícola de Montilla; Data Sheet; Consejería de Cultura: Sevilla, Spain, 2016.

23. Ramírez Pino, J. Montilla, 1950-1975. In Entre La Historia Y La Memoria; Montilla: Cordoba, Spain, 1994.

24. Triviño-Tarradas, P.M. Evolución y mejoras para el manejo sostenible de la explotación vitivinícola en la D.O.P. Montilla-Moriles. Evaluation and Improvements for the Sustainable Management of the Wine-Making Farm in the PDO Montilla-Moriles. Ph.D. Thesis, University of Cordoba, Cordoba, Spain, 2019.

25. Badia-Miró, M.; Tello, E.; Valls, F.; Garrabou, R. The grape phylloxera plague as a natural experiment: The upkeep of vineyards in catalonia (spain), 1858-1935. Aust. Econ. Hist. Rev. 2010, 50, 39-61. [CrossRef]

26. Duran, J.I.D.L. Wine cathedrals: Making the most of masonry. Proc. Inst. Civ. Eng. Constr. Mater. 2013, 166, 329-342. [CrossRef]

27. Instituto de Estadística y Cartografía de Andalucía. Consejería de Economía y Conocimiento. Atlas de Histórica Económica de Andalucía. SS XIX-XX. 2020. Available online: https://www.juntadeandalucia.es/institutodeestadisticaycartografia/ atlashistoriaecon/atlas_cap_17.html (accessed on 19 April 2021).

28. Consejo Regulador de Montilla-Moriles. Estadísticas. 2020. Available online: https://www.montillamoriles.es/es/ (accessed on 28 April 2021).

29. Baraja Rodríguez, E.; Plaza Gutiérrez, J.I.; Prada Llorente, E.I. Naturaleza, Territorio y Ciudad en un Mundo Global. Actas del XXV Congreso de la Asociación de Geógrafos Españoles. In Atributos y Valores Patrimoniales de los Viñedos Tradicionales en las Provincias de Zamora y Salamanca: El caso de los arribes del Duero; A.G.E. (ASOCIACIÓN GEÓGRAFOS ESPAÑOLES): Madrid, Spain, 2017.

30. Valdés, M. Montilla y Su Comarca: Enciclopedia-Guía Antológica; Valdés M.: Sevilla, Spain, 1979.

31. González San José, M.L. Enoturismo y Entornos Sostenibles. 2017, Volume 193, p. a399. Available online: http:/ / arbor.revistas.csic. es/index.php/arbor/article/view/2207 (accessed on 20 May 2021).

32. Pardo Abad, C.J. El Patrimonio Industrial En España: Análisis Turístico Y Significado Territorial De Algunos Proyectos De Recuperación; Boletín de la Asociación de Geógrafos Españoles: Seville, Spain, 2010; Volume 53, pp. 239-264.

33. García, N.T. La Memoria del Pasado Industrial. Conservación, Reutilización Y Creación De Nuevos Equipamientos. RPH Rev. Electrónica Patrim. Histórico 2016, 19, 72-99. 
34. Mansilla Plaza, L. El Parque Minero de Almadén. Un Modelo De Recuperación Del Patrimonio Minero Industrial. Herit. Museography 2011, 1, 13-24.

35. Arnáiz, M.M.; Rodríguez, E.B.; Hernando, F.M. Criterios de la UNESCO para la declaración de regiones vitícolas como paisaje cultural: Su aplicación al caso español. BAGE 2019, 80, 2614. [CrossRef]

36. Martínez Carrión, J.M.; Ramon Muñoz, J.M. La vitivinicultura y la valorización de su patrimonio industrial, cultural y natural. In Áreas. Revista Internacional De Ciencias Sociales; University of Murcia: Murcia, Spain, 2010; Volume 29, pp. 148-155. Available online: https:/ / revistas.um.es/areas/article/view/115631 (accessed on 18 May 2021).

37. Aladro-Prieto, J.M. Bodegas, Lagares y Casas de Viñas. AH Andalucía en la Historia, año XVII, 66, Octubre-Diciembre. 2019; pp. 14-17. Available online: https://www.centrodeestudiosandaluces.es/publicaciones/descargando/2356/documento (accessed on 18 May 2021).

38. Álvarez-Areces, M.A. Patrimonio industrial. Un futuro para el pasado desde la visión europea. In APUNTES; 2008; Volume 21, núm. 1; pp. 6-25. Available online: http://www.scielo.org.co/pdf/apun/v21n1/v21n1a02.pdf (accessed on 18 May 2021).

39. Luque Romero, F.; Agudo Torrico, J.; Cobos, J. Cultura Material De Carácter Tradicional En La Provincia De Córdoba; Gever S.L.: Cordoba, Spain, 1985; Volume IV, pp. 137-193.

40. Marine, N.; Arnaiz-Schmitz, C.; Herrero-Jáuregui, C.; Cabeza, M.R.O.; Escudero, D.; Schmitz, M.F. Protected Landscapes in Spain: Reasons for Sustainability of Conservation Management. Sustainability 2020, 12, 6913. [CrossRef]

41. Sobrino Simal, J. Arquitectura de la industria en Andalucía; Instituto de Fomento de Andalucía: Jaen, Spain, 1998.

42. Bellido Vela, I.D. Diego de Alvear y Ward. Un innovador de la agroindustria. La prensa hidráulica. Ph.D. Thesis, University of Cordoba, Cordoba, Spain, 2016.

43. Llamas Salas, M. El molino del duque de Montilla Y La Influencia Del Monopolio Señorial En La Arquitectura Oleícola. Ph.D. Thesis, University of Cordoba, Cordoba, Spain, 2016.

44. Archivo Histórico Municipal de Montilla (Cordoba-Spain). Legajo 980 B, Expediente 1. Available online: https://www.montilla. es/areas_municipales/cultura/archivo_historico (accessed on 20 May 2021).

45. Montesinos, F.J.A. Reconstrucción virtual del lagar El Parador. Unpublished Master's Degree Project, University of Cordoba, Córdoba, Spain. 2012. Available online: https:/ /www.youtube.com/watch?v=rmjGV76s_n8 (accessed on 26 April 2021).

46. Junta de Andalucía. Consejería de Cultura y Patrimonio Histórico. Guía Digital del Patrimonio Cultural de Andalucía. 2020. Available online: https:/ / guiadigital.iaph.es/inicio (accessed on 15 April 2021).

47. Muñoz, P.; Morales, M.; Mendívil, M.; Juárez, M.; Muñoz, L. Using of waste pomace from winery industry to improve thermal insulation of fired clay bricks. Eco-friendly way of building construction. Constr. Build. Mater. 2014, 71, 181-187. [CrossRef]

48. Cruz Marqués, M. Evolución del diseño de proyectos de bodegas de vinos en la provincia de Córdoba; University of Cordoba: Cordoba, Spain, 1998.

49. Torres, J.; Cano, P.; Melero, J.; España, M.; Moreno, J. Aplicaciones de la digitalización 3D del patrimonio. Virtual Archaeol. Rev. 2010, 1, 51-54. [CrossRef]

50. Bekele, M.K.; Pierdicca, R.; Frontoni, E.; Malinverni, E.S.; Gain, J. A Survey of Augmented, Virtual, and Mixed Reality for Cultural Heritage. J. Comput. Cult. Herit. 2018, 11, 1-36. [CrossRef] 